\title{
Pioglitazone alters monocyte populations and stimulates recent thymic emigrants in the BBDZR/Wor type 2 diabetes rat model
}

\author{
Bradley T. Gao' ${ }^{1}$ Ryan P. Lee', Youde Jiang ${ }^{1}$, Jena J. Steinle ${ }^{1,2,4}$ and Vanessa M. Morales-Tirado 1,3*
}

\begin{abstract}
Background: Type 2 diabetes is commonly characterized by insulin deficiency and decreased sensitivity of insulin receptors, leading to a chronic state of hyperglycemia in individuals. Disease progression induces changes in the immune profile that engenders a chronic inflammatory condition. Thiazolidinedione (TDZ) drugs, such as Pioglitazone (Pio), aid in controlling disease symptoms. While the mechanisms by which Pio controls hyperglycemia are beginning to be understood, relatively little is known about the effects of Pio on suppression of the systemic immune phenotype, attributed to visceral adipose tissue and macrophages.
\end{abstract}

Methods: Here, we utilize the recently developed BBDZR/Wor type 2 diabetes rat model to test our hypothesis that a selective in vivo growth of $\mathrm{CD}^{+} \mathrm{T}$ cells in the spleen contributes to the increase in T lymphocytes, including Tregs, independent of visceral adipose tissue. We investigated the systemic effects of Pio on multifactorial aspects of the disease-induced immune phenotype both in vivo and in vitro in normal, non-diabetic animals and in disease.

Results: Our work revealed that Pio reversed the lymphopenic status of diabetic rats, in part by an increase in $\mathrm{CD}^{+} \mathrm{T}$ lymphocytes and related subsets. Moreover, we found evidence that Pio caused a selective growth of newly differentiated T lymphocytes, based on the presence of recent thymic emigrants in vivo. To investigate effects of Pio on the inflammatory milieu, we examined the production of the signature cytokines TNF- $\alpha$ and IL-1 $\beta$ and found they were reduced by Pio-treatment, while the levels of IL-4, an anti-inflammatory mediator, were significantly increased in a Pio-dependent manner. The increase in IL-4 production, although historically attributed to macrophages from visceral adipose tissue under other conditions, came also from $\mathrm{CD}^{+} \mathrm{T}$ lymphocytes from the spleen, suggesting splenocytes contribute to the Pio-induced shift towards an anti-inflammatory phenotype.

Conclusions: We show for the first time that Pio treatment significantly suppresses the systemic inflammatory status in the BBDZR/Wor type 2 diabetes rat model by the selective growth of newly differentiated $\mathrm{CD}^{+} \mathrm{T}$ cells and by increasing $\mathrm{CD}^{+} \mathrm{IL}-4$ production in immigrant spleen lymphocytes.

Keywords: Pioglitazone, Type 2 diabetes, Immunomodulation, Recent thymic emigrants

\section{Background}

Due to a persistent rise in incidence, type 2 diabetes affects 29.1 million Americans, or $9.3 \%$ of the US

\footnotetext{
*Correspondence: Vmorale1@uthsc.edu

${ }^{3}$ Department of Microbiology, Immunology and Biochemistry, College of Medicine, The University of Tennessee Health Science Center, Memphis, TN 38163, USA

Full list of author information is available at the end of the article
}

population, and the disease ranks as the 7 th leading cause of death in 2010 [1-3]. In 2012, diabetes and its complications accounted for over $\$ 245$ billion in direct medical costs and indirect expenses related to wages and lost work. Type 2 diabetes represents $90 \%$ of the total cases diabetes mellitus nationwide, and current treatment options range from exercise and diet modification to pharmaceutical interventions that augment insulin 
sensitivity and alleviate hyperglycemia [1]. While many of the pathological consequences of type 2 diabetes are related to chronic hyperglycemia, the onset and progression of this disease also leads to a dysregulation of the immune response, resulting in chronic inflammation [4]. Therefore, in addition to combating the effects of glucose toxicity, effective treatments must concurrently mitigate the activation of inflammatory mediators in order to prevent immune-mediated pathology [4].

Thiazolidinediones (TZDs) are a common class of drugs prescribed to patients with type 2 diabetes. TZDs, such as rosiglitazone and pioglitazone, are used to lower systemic glucose concentration by insulin sensitivity [ 5 , 6]. These compounds function as peroxisome proliferator-activated receptor gamma (PPAR $\gamma)$ agonists [7]. Activation of PPAR $\gamma$ in tandem with the retinoid $X$ receptor modulates regulatory effects on inflammatory target genes $[8,9]$. The cumulative result is decreased insulin resistance [10-13], modification of adipocyte differentiation [11, 12, 14, 15], decreased leptin levels [16], and decreased mean arterial pressure [13].

The present study aimed to assess the mechanisms responsible for systemic effects of Pioglitazone (Pio) on the immunoregulation of lymphocytes and monocytes. For these studies, we analyzed secondary immune organs in the recently developed BBZDR/Wor type 2 diabetes rat model, thus allowing us to examine effects of Pio on altered systemic immune function associated with the disease status. Past studies have examined anti-inflammatory mechanisms of PPAR $\gamma$ agonists, such as Pio and Ciglitazone [17-19], and report down-regulation of macrophages $[20,21]$ and modulation of $\mathrm{T}$ cell activation [22-24]. However, most of these studies focus on analyses of the macrophage and regulatory $\mathrm{T}$ cell population in adipose tissue and not in immune organs such as the spleen and liver. Here, we demonstrate a selection for in vivo growth of $\mathrm{T}$ lymphocytes, indicated by an increase in recent thymic emigrants, as a result of Pio treatment in BBDZR/Wor rats. Furthermore, to investigate extra-splenic contributions, we studied the in vitro effects of Pioglitazone in normal, non-diabetic, splenocytes and demonstrate an increase in $\mathrm{T}$ cells, including regulatory $\mathrm{T}$ cells, and in monocytes, independent of the presence of visceral adipose tissue.

\section{Methods}

\section{Animals}

Male obese and lean (non-diabetic) littermates BBZDR/ Wor rats were purchased from Biomedical Research Models (Worchester, MA). Obese: diabetic model; lean littermates: non-diabetic, control group. Any obese rat that did not show glucose levels $>250 \mathrm{mg} / \mathrm{dL}$ were excluded from the study. Five rats from each group received a daily intraperitoneal (i.p., $1 \mathrm{~mL}$ final volume) injection of $25 \mathrm{mg} / \mathrm{kg}$ Pioglitazone or vehicle (5\% DMSO) for 2 months, as described in [19], followed by sacrifice for analyses. All animal experiments were approved by The University of Tennessee Health Science Center Institutional Animal Care and Use Committee.

\section{Glucose measurements}

Rats underwent glucose measurements by glucose strip readings, as we previously described [25]. Rats glucose levels $>250 \mathrm{mg} / \mathrm{dL}$ were considered diabetic [19].

\section{Tissue culture experiments}

Splenocytes and hepatocytes were isolated by physical disruption using the back end of a syringe on a $70 \mu \mathrm{M}$ nylon strainer. Cell suspension was washed and Red Blood Cell (RBC) contaminants were eliminated using RBC Lysis Buffer (BioLegend, San Diego, CA, USA) following manufacturer's instructions. Cells $\left(5.0 \times 10^{5}\right.$ cells $\left./ \mathrm{mL}\right)$ were cultured in a 24-well plate in $\mathrm{RPMI} / 10$ \% FBS/1 \% Pen/Strep media. In vitro conditions included $\pm 25 \mu \mathrm{M}$ Pioglitazone (Pio; Sigma-Aldrich, St. Louis, MO, USA) for $24 \mathrm{~h}$. Ex vivo cell activation was done using Phorbol 12-myristate 13-acetate (PMA; Sigma-Aldrich) at a concentration of $100 \mathrm{ng} / \mathrm{mL}$ for $6 \mathrm{~h}$. Golgi Stop ${ }^{\circledR}$ was added ( $1 \mu \mathrm{L}$ per $1 \mathrm{~mL}$ of culture) for the last $4 \mathrm{~h}$ of incubation prior to harvest to inhibit cytokine transport.

\section{Surface molecule labeling}

Cell suspensions were washed in Staining Buffer (PBS/1 \% FBS) prior to labeling. Cells were labeled for 30 min protected from light on ice bucket. Once labeled cells were washed multiple times with Staining Buffer and analyzed immediately. The following anti-rat antibodies were used: anti-CD3 AF-647, anti-CD4 PE-Cy7, anti-CD11b/c APC, anti-CD25 FITC, and anti-CD31 Biotin/Streptavidin Brilliant Violet 421 (SA-bv421), all from BioLegend (San Diego, CA, USA). For each antibody we used the respective Immunoglobulin G (IgG) isotype control. In addition, we used single label control $\mathrm{Abc}^{\text {TM }}$ Capture Beads (Life Technologies). Data acquired in BD Biosciences LSRII Flow Cytometer and analyses were done using FlowJo vX.10.0.6 software (Tree Star, OR).

\section{Intracellular assay}

Following cell surface labeling, cells were fixed using eBioscience FoxP3 Fixation/Permeabilization Buffer (eBiosciences), followed by intracellular labeling for $30 \mathrm{~min}$ with either anti-rat FoxP3 PE or isotype control PE. Cells were washed multiple times prior acquisition and analysis. 


\section{Western blot}

Cells were lysed in $25 \mu \mathrm{L}$ of Lysis Buffer as previously described [26]. Protein concentrations were determined using Pierce $^{\mathrm{TM}}$ BCA Protein Assay Kit (Thermo Scientific). A total of $30 \mu \mathrm{g}$ of denatured protein was used for each sample loaded in a Novex ${ }^{\circledR} 4-12 \%$ Tris-Glycine Gel (Life Technologies). Membrane was blocked in $20 \mathrm{~mL}$ of $5 \%$ BSA in TBS-Tween 20 and incubated overnight at $4{ }^{\circ} \mathrm{C}$ in 1:1000 PPAR $\gamma$ rabbit monoclonal antibody (Cell Signaling Technologies) followed by 1:1000 anti-rabbit secondary antibody solution for $1 \mathrm{~h}$ at RT. Once completed, the membrane was washed and probed for $\beta$-actin as control (Cell Signaling Technologies). SuperSignal West Pico Chemiluminiscent Substrate (Thermo Scientific) was used. Densitometry analysis was done using Kodak Molecular Imager.

\section{Statistics}

Mann-Whitney U tests were used for Western Blot data and student $\mathrm{t}$ tests were used for flow cytometry analysis. Data was analyzed using GraphPad software (GraphPad Software, Inc., La Jolla, CA, USA). Values of $p<0.05$ were considered significant.

\section{Results}

\section{Pio eliminates hyperglycemia without a reduction} in adipose tissue

Recently, we provided evidence that Pio improved retinal insulin signaling in the BBZDR/Wor type 2 diabetes rat model in a PPAR $\gamma$-dependent manner [19]. Pio reduced TNF- $\alpha$ and SOCS3-activated insulin resistance pathways in the retina and protected against diabetic retinopathy [19]. As a next step, we wanted to assess the systemic immunomodulatory effects of Pio on BBZDR/Wor rats under the same treatment conditions.

First, we confirmed the efficacy of Pio in reducing hyperglycemia in this model. Ten obese diabetic BBZDR/Wor rats and ten lean non-diabetic littermates were randomized into treatment or control, yielding four groups (diabetic, diabetic + Pio, non-diabetic, non-diabetic + Pio). For the five rats in each of the two treatment groups, $25 \mathrm{mg} / \mathrm{kg}$ of Pio was injected intraperitoneally each day for 2 months. Figure 1a shows a dramatic reduction in blood glucose levels in the diabetic rats after Pio treatment $(p<0.05)$. Consistent with established mechanisms of Pio action, glucose reduction was not associated with loss of body mass (diabetic versus non diabetic: $383 \pm 14.8$ versus $105.3 \pm 20.8$; $p=0.0002$; diabetic + Pio versus diabetic: $93.4 \pm 28.1$ versus $383 \pm 14.8 ; p=0.0140$ ). Moreover, Pio-treated rats gained weight compared to untreated diabetic rats (Fig. 1b, diabetic versus non diabetic: $623 \pm 12.3$ versus $457 \pm 29.7 ; p=0.0002$; diabetic + Pio versus diabetic:
$820.8 \pm 75.9$ versus $623 \pm 12.3 ; p=0.0018$ ). These results confirm that the effect of Pio on glucose normalization and the immunophenotype is independent of loss of adipose tissue.

\section{Pio mitigates lymphopenia in BBZDR/Wor rats}

In addition to hyperglycemia and obesity, diabetic BBZDR/Wor rats have reduced numbers of circulating $T$ lymphocytes compared to their non-diabetic lean littermates. Using splenocytes as an indicator of the systemic immunophenotype, we next determined differences in the relative levels of $\mathrm{CD}^{+}$and $\mathrm{CD}^{+}{ }^{+} \mathrm{CD} 4^{+}$splenocyte subtypes between the groups. As shown in Table 1 and Fig. 1c, the percentage of $\mathrm{CD}^{+}$and $\mathrm{CD}^{+}{ }^{+} \mathrm{CD} 4^{+} \mathrm{T}$ cells among splenocytes is lower in the untreated diabetic rats compared to untreated non-diabetic lean controls $\left[\mathrm{CD} 3^{+}\right.$: $10.7 \% \pm 3.0$ versus $86.4 \% \pm 2.8$, respectively, $p=0.0087$; $\mathrm{CD}^{+}{ }^{+} \mathrm{CD} 4^{+}: 11.0 \% \pm 8.4$ versus $53.1 \% \pm 10$, respectively, $p=0.0043$; (mean $\pm \mathrm{SD}$ )]. Treatment of non-diabetic rats with Pio had no significant effect on the percentage of $\mathrm{CD}^{+} \mathrm{T}$ cells $(86.2 \% \pm 0.5, p=0.4474)$ and a marginally, but not significant increase on the percentage of $\mathrm{CD}^{+}{ }^{+} \mathrm{CD} 4^{+} \mathrm{T}$ cells $(p=0.05)$. However, treatment of the diabetic rats with Pio significantly increased the percentage of both $\mathrm{CD}^{+}(64.3 \% \pm 3.3$ versus $10.7 \% \pm 3.0$, $p=0.0135)$ and $\mathrm{CD}^{+}{ }^{+} \mathrm{CD} 4^{+} \mathrm{T}$ cells $(27.3 \% \pm 3.9$ versus $11.0 \% \pm 8.4, p=0.0302)$. This increase reversed the lymphopenia observed in the diabetic obese rats compared to their non-diabetic littermates.

\section{In vivo increase of T lymphocytes by Pio correlates with increase in recent thymic emigrants}

To investigate the origin of this Pio-stimulated population of lymphocytes, we labeled splenocytes in each group with anti-CD31 monoclonal antibody. Positivity of $\mathrm{CD} 31$ among $\mathrm{CD}^{+} \mathrm{CD}^{+} \mathrm{T}$ lymphocytes is a marker of recent thymic emigration (reviewed in [27]). Figure 1d demonstrates a significant increase in the percentage of $\mathrm{CD}^{+} \mathrm{CD}^{+}{ }^{+} \mathrm{CD} 31^{+}$splenocytes after Pio treatment in both diabetic $(13.2 \% \pm 1.0$ versus $34.2 \% \pm 2.3$, $p=0.0011)$ and non-diabetic rats $(34.1 \% \pm 2.6$ versus $47.4 \% \pm 0.6, p<0.005)$. These results suggest a Piodependent amelioration of lymphopenic status in the BBZDR/Wor diabetic rats due, at least in part, to lymphocyte emigration from the thymus after Pio treatment.

\section{In vivo decrease in pro-inflammatory cytokines (TNF-a and IL-1 $\beta$ ) and increase in anti-inflammatory cytockine, IL-4, after Pio treatment}

As has been extensively shown and reviewed [28-34], states of obesity and hyperglycemia upregulate proinflammatory cytokines both locally and systemically. To confirm that the diabetic BBZDR/Wor rats exhibit 
$\mathbf{a}$

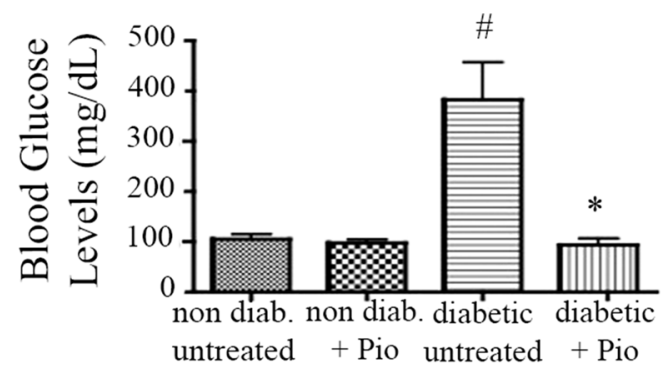

C


b

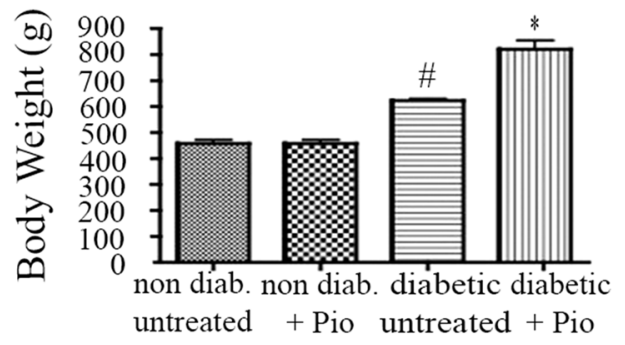

d

untreated
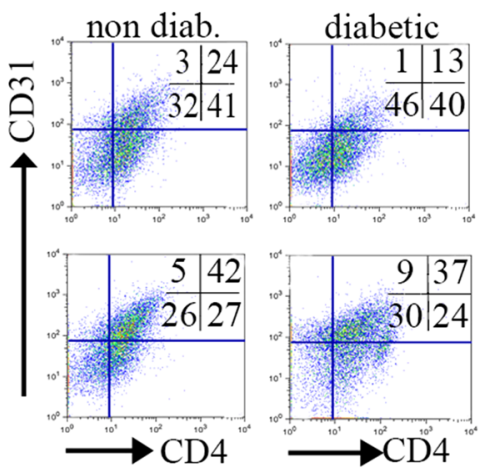

Fig. 1 Pioglitazone eliminates hyperglycemia and mitigates lymphopenia in BBZDR/Wor diabetic rats. a, b Pioglitazone-dependent reduction in glucose levels is independent of weight. BBDZR/Wor diabetic and non-diabetic (littermates) rats were injected daily intraperitoneally with either $25 \mathrm{mg} / \mathrm{kg}$ pioglitazone or vehicle (5 \% DMSO) for 2 months. Each group had 5 rats ( $\left.{ }^{*} p<0.05,{ }^{\sharp} p<0.0002 ; \mathbf{b}^{*} p=0.0002,{ }^{*} p=0.0018\right)$. c Pioglitazone restores diabetic-induced lymphopenic status. Splenocytes from all four groups were examined for the percentage of $C D 3^{+} C D 4^{+} \mathrm{T}$ cells using rat anti-CD3 Alexa Fluor 647 and anti-CD4 PE-Cy7 antibodies. Upper representative pseudocolor plot of 1 rat per condition. Lower quantitation of the flow cytometry analysis $\left(\mathrm{n}=3 ;{ }^{*} p=0.0087,{ }^{\#} p=0.0043\right)$. $\mathbf{d}$ In vivo increase in percentage of T lymphocytes is partly attributed to increase in recent thymic emigrants. Gated CD3 ${ }^{+}$T cells were examined for CD4 and CD31 immunoreactivity by using rat anti-CD4 PE-Cy7 and rat anti-CD31 Biotin/ Streptavidin bv421, respectively. Upper representative plot of 1 rat per condition. Lower quantitation analysis $\left(n=3 ;{ }^{*} p<0.005,{ }^{*} p=0.0011\right)$

these pathologic changes, we investigated the percentage of $\mathrm{CD}^{+}$splenocytes producing the pro-inflammatory cytokines TNF-a and IL-1 $\beta$. As expected, diabetic rats showed an increase in the percentage of $\mathrm{CD} 3^{+} \mathrm{TNF}-\mathrm{a}$-producing cells compared to the nondiabetic $(11.7 \% \pm 1.2$ versus $4.4 \% \pm 1.3, p<0.005$, Fig. 2a). Furthermore, our data suggests splenic lymphocytes contribute, at least part, to the pro-inflammatory cytokine milieu. Our results suggest that at least part of that action, in the case of Pioglitazone, is due to reduction of the $\mathrm{CD}^{+} \mathrm{T}$ cells that produce TNF- $\alpha$ and IL-1 $\beta$. Diabetic rats treated with Pio had a lower percentage of $\mathrm{CD}^{+} \mathrm{TNF}-\alpha$-producers $(1.8 \% \pm 1.7$ versus $11.7 \% \pm 1.2$ in controls; $p<0.05$, Fig. 2a). Similarly, $\mathrm{CD}^{+} \mathrm{IL}-1 \beta-$ producers were reduced from $5.0 \% \pm 1.4$ to $1.3 \% \pm 1.6$ $(p<0.05$, Fig. 2b). 
Table 1 Splenocyte immunophenotypes after treatment with Pioglitazone in vitro and in vivo

\begin{tabular}{|c|c|c|c|c|c|c|}
\hline & \multicolumn{2}{|l|}{ In vitro } & \multicolumn{4}{|l|}{ In vivo } \\
\hline & Non-diab. & Non-diab. + Pio & Non-diab. & Non-diab. + Pio & Diabetic & Diabetic + Pio \\
\hline $\mathrm{CD}^{+}$ & $14.4 \% \pm 0.4$ & $17.8 \% \pm 1.0^{*}$ & $86.4 \% \pm 2.8$ & $86.2 \% \pm 0.5$ & $10.7 \% \pm 3.0^{*}$ & $64.3 \% \pm 3.3^{*}$ \\
\hline $\mathrm{CD}^{+} \mathrm{CD}^{+}$ & $12.7 \% \pm 0.7$ & $3.7 \% \pm 0.3^{\#}$ & $53.1 \% \pm 10$ & $50.0 \% \pm 8.8$ & $11 \% \pm 8.4^{\#}$ & $27.3 \% \pm 3.9^{\#}$ \\
\hline $\mathrm{CD}^{+}{ }^{+} \mathrm{CD} 4^{+} \mathrm{CD} 25^{+}$ & $6.6 \% \pm 0.4$ & $33.1 \% \pm 3.4^{\sharp}$ & $12.4 \% \pm 1.8$ & $19.0 \% \pm 0.5$ & $4.6 \% \pm 2.1^{\natural}$ & $36.2 \% \pm 7.1^{1}$ \\
\hline
\end{tabular}

Splenocytes were labeled with rat anti-CD3 AF-647, anti-CD4 PE-Cy7, and anti-CD25 FITC. Results are $\% \pm$ SD, $\mathrm{n}=3$

In vitro non-diabetic + Pio versus non-diabetic: ${ }^{*} p=0.0085,{ }^{*} p=0.0006,{ }^{\natural} p=0.0022$

In vivo diabetic versus non-diabetic (1): ${ }^{*} p=0.0087,{ }^{\#} p=0.0043,{ }^{n} p=0.0040$

Diabetic + Pio versus Diabetic (2): ${ }^{*} p=0.0135,{ }^{*} p=0.0302,{ }^{\natural} p=0.0178$

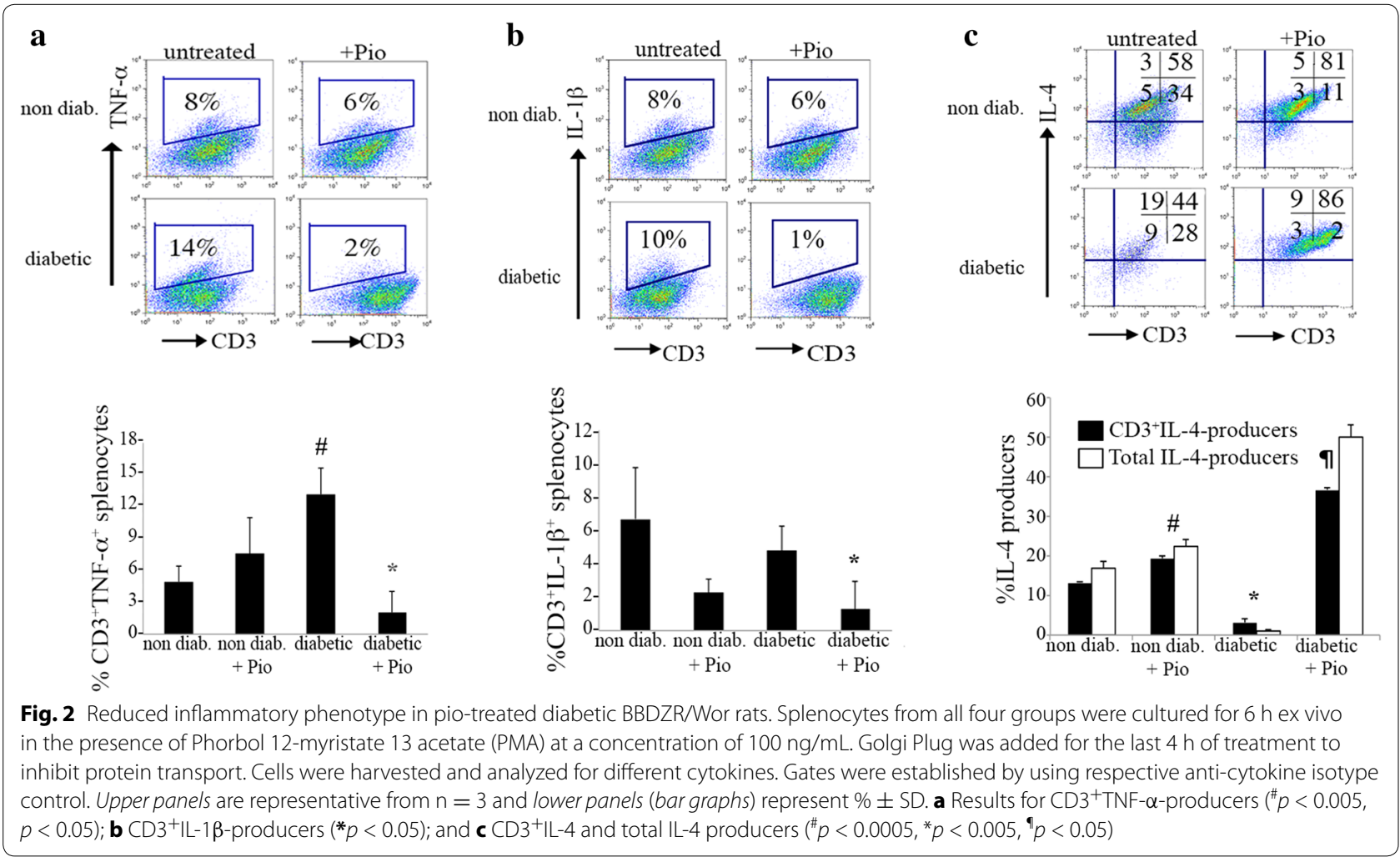

Next, we addressed if the reduction in pro-inflammatory mediators was accompanied by an increase in antiinflammatory cytokines, such as IL-4. First, we show BBZDR/Wor diabetic rats have significantly diminished levels of $\mathrm{CD}^{+}{ }^{+} \mathrm{IL}_{-} 4^{+}$splenocytes compared to nondiabetics $(1.1 \% \pm 0.1$ versus $13.5 \% \pm 1.3$, respectively $p<0.005$, Fig. 2c). As expected, there was a shift towards an anti-inflammatory phenotype with a significant increase in $\mathrm{CD}^{+} \mathrm{IL}-4$-producers in the spleen in both the non-diabetic and the diabetic treated groups (non-diabetic: $13.5 \% \pm 1.3$ to $22.2 \% \pm 1.9, p<0.0005$; diabetic: $1.1 \% \pm 0.1$ to $30.4 \% \pm 15, p<0.05$; Fig. 2 c). Previous reports showed the source of IL-4 production was from a macrophage population within adipose tissue, termed M2 [35, 36]. To investigate the relative contribution of the $\mathrm{CD}^{+} \mathrm{T}$ cell population to the total IL-4 production, we analyze for the total IL-4-producer cells, comprising both $\mathrm{CD}^{+}$and $\mathrm{CD} 3^{\text {neg }}$ cells. Our results revealed that $\mathrm{CD}^{+} \mathrm{T}$ cells are large contributors, in both the non diabetic and diabetic groups, as shown in Fig. 2c. $\mathrm{CD}^{+}$contribution to the IL-4-producers in the non-diabetic + Pio group was 43.9 versus $80.2 \%$ in the diabetic + Pio group. Together, these results implicate $\mathrm{CD}^{+}$splenocytes as contributors to the loss of anti-inflammatory signaling 
associated with diabetes. Furthermore, Pio treatment is able to recover critical regulatory balance in the immunophenotype.

\section{Pio reduces $\mathrm{CD} 11 \mathrm{~b} / \mathrm{c}^{+}$population in BBZDR/Wor rats}

Recent literature has placed a significant emphasis on macrophages, particularly those in adipose tissue, as drivers of obesity-related inflammation and subsequent insulin resistance [37, 38]. Specifically, there is a decrease in anti-inflammatory M2 macrophages and a reciprocal increase in pro-inflammatory M1 macrophages. These M1 macrophages are defined as $\mathrm{CD} 11 \mathrm{c}^{+}$, which have been shown to increase in adipose tissue with obesity [39]. We labeled Pio-treated and untreated splenocytes with an anti-CD11b/c antibody that reacts with a common epitope within the CR3 complement receptor (C3bi) shared by CD11b and CD11c. This epitope is non-exclusive, as it is present in monocytes, dendritic cells, macrophages, and other immune cells. The percentage of splenocytes expressing this marker was higher in diabetic rats compared to non-diabetic littermates (19 versus $8 \%$; 2.4-fold increase, Fig. 3a). After Pio treatment, the percentage of $\mathrm{CD} 11 \mathrm{~b} / \mathrm{c}^{+}$splenocytes decreased to levels comparable to non-diabetic controls (diabetic: $10 \%$, non-diabetic: $9 \%$ ). Interestingly, Pio treatment did not significantly affect levels of this marker among treated and untreated non-diabetic rats (9 and $8 \%$, respectively). Next, we analyzed these $\mathrm{CD} 11 \mathrm{~b} / \mathrm{c}^{+}$cells by examination of CD4 positivity. Although the percentage of CD11b/ $\mathrm{c}^{+}$cells was higher in diabetic rats, a much smaller percentage of these cells were $\mathrm{CD}^{+}(23 \%$ in diabetic versus $41 \%$ in non-diabetic, Fig. 3b). Pio treatment partially reversed this imbalance by increasing the percentage of $\mathrm{CD} 4^{+}$among the $\mathrm{CD} 11 \mathrm{~b} / \mathrm{c}^{+}$population in the diabetic rats from 23 to $33 \%$.

Reduction of $\mathrm{CD}^{+}{ }^{+} \mathrm{T}$ lymphocytes, increase in regulatory $\mathrm{T}$ cells $\left(\mathrm{CD}^{+}{ }^{+} \mathrm{CD}_{4}{ }^{+} \mathrm{CD}_{25}{ }^{+} \mathrm{FoxP}^{+}\right.$) and modulation of $\mathrm{CD} 11 \mathrm{~b} /$ $\mathrm{C}^{+}$cells after Pio treatment in vitro

After establishing that Pio treatment of BBZDR/Wor diabetic rats mitigates several aspects of the pro-inflammatory immunophenotype, we investigated which specific effects were mediated by extra-splenic mechanisms and which were due to direct effects by splenocytes. Splenocytes from non-diabetic rats were cultured in vitro for $24 \mathrm{~h}$ in the presence or absence of $25 \mu \mathrm{M}$ Pio. Western blot analysis showed no statistical difference $(p=0.35$; $n=3$ ) in the levels of PPAR $\gamma$ protein relative to $\beta$-actin in splenocytes cultured with or without Pio (Fig. 4a, left). For comparison, we cultured hepatocytes from the same rats under the same conditions. Figure $4 \mathrm{a}$, right demonstrates that levels of PPAR $\gamma$ protein levels in

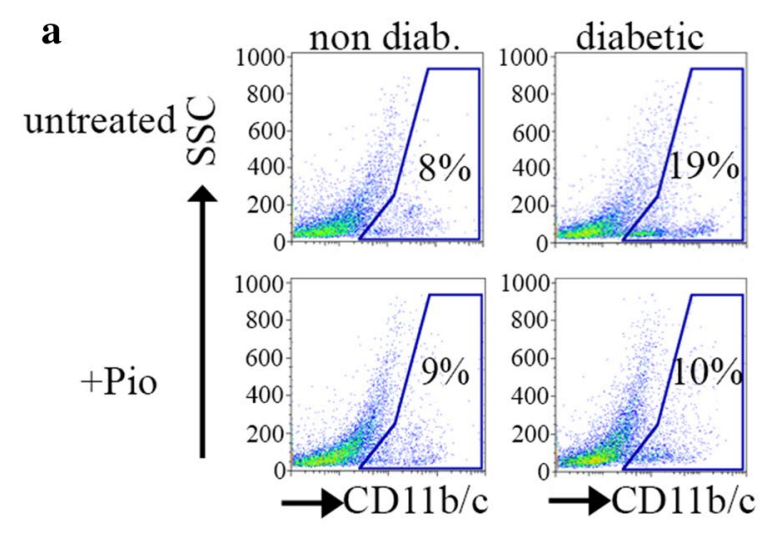

b

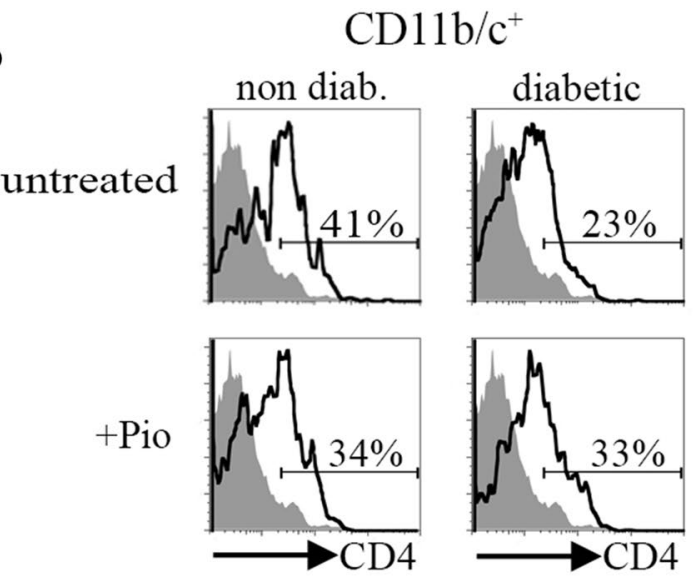

Fig. 3 Pioglitazone alters $C D 11 \mathrm{~b} / \mathrm{c}^{+}$population in splenocytes of BBZDR/Wor rats. a Splenocytes from all groups were labeled with rat anti-CD11b/c APC. b Gated population in panel a examined for expression of CD4. Figures are representative of 2-pooled splenocytes per condition

hepatocytes treated with Pio although higher, are not significant $(p=0.05, \mathrm{n}=3$ ).

Next, we examined the percentage of total $\mathrm{CD}^{+} \mathrm{T}$ lymphocytes in splenocytes cultured in the presence of Pio. As we found in vivo, the percentage of $\mathrm{CD}^{+}$cells present in splenocyte cultures increased after treatment $(17.8 \% \pm 1.0$ treated versus $14.4 \pm 0.4$ control, $p=0.0085$ ) (shown in Table 1 and Fig. 4b). Furthermore, there was a prominent down-regulation of the CD4 coreceptor among $\mathrm{CD}^{+}$cells, as $3.7 \% \pm 0.3$ of Pio-treated splenocytes exhibited a $\mathrm{CD}^{+} \mathrm{CD}^{+}$phenotype compared to $12.4 \% \pm 0.6$ in untreated cells $(p=0.0006)$. These results suggests that the in vivo increase in $\mathrm{CD}^{+}{ }^{+} \mathrm{CD} 4^{+}$cells in the diabetic rat spleens was in large part due to recent thymic emigration after Pio treatment. Additionally, Pio treatment exerted significant effects without upregulating PPAR $\gamma$ protein levels. We 


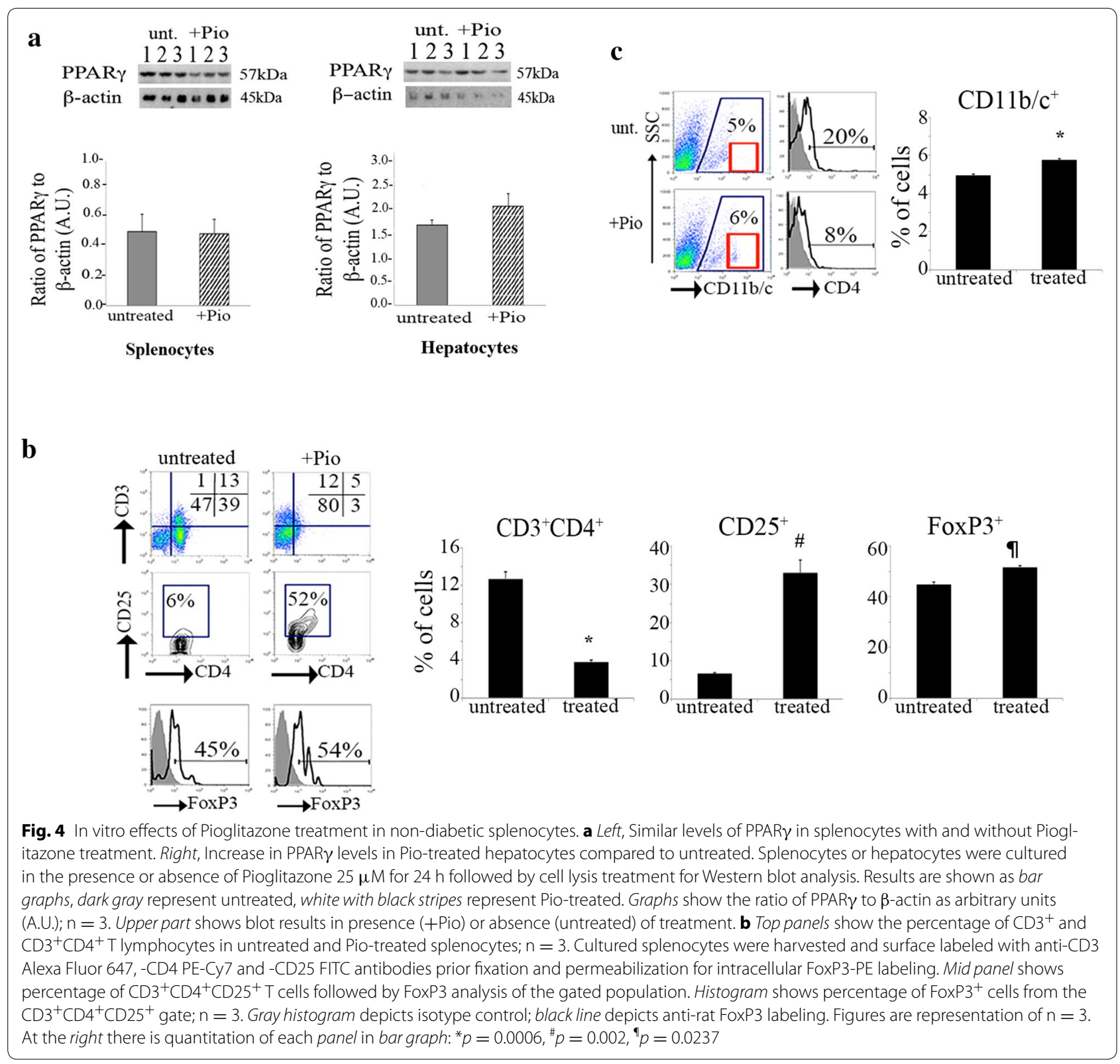

further characterized the $\mathrm{CD}^{+} \mathrm{CD}^{+}$subset to evaluate the percentage of $\mathrm{CD}_{3}{ }^{+} \mathrm{CD} 4^{+} \mathrm{T}$ lymphocytes immunoreactive against CD25. Upregulation of the IL-2R $\alpha$ chain, CD25, is associated with an activated and immunoregulatory phenotype. We hypothesized that CD25 expression would be increased and partially responsible for the anti-inflammatory transition after Pio treatment. Figure $4 \mathrm{~b}$ shows the percentage of $\mathrm{CD}^{+} \mathrm{CD} 4^{+} \mathrm{CD} 25^{+}$ $\mathrm{T}$ lymphocytes in untreated versus Pio-treated cells. In the untreated samples, an average of $6.6 \% \pm 0.4$ of $\mathrm{CD}^{+}{ }^{+} \mathrm{CD} 4{ }^{+}$cells co-expressed CD25 (Table 1). However, Pio-treated splenocytes showed an increased percentage of $\mathrm{CD}^{+} \mathrm{CD}^{+}{ }^{+} \mathrm{CD} 25^{+} \mathrm{T}$ cells: $33.1 \% \pm 3.4(p=0.0022)$. To further explore this immunomodulation we monitored the percentage of cells that were FoxP3 positive, a well-established marker for immunoregulatory phenotype associated with relative immunosuppression [40-42]. While both groups showed a large population of $\mathrm{CD}^{+} \mathrm{CD}^{+}{ }^{+} \mathrm{CD} 25^{+} \mathrm{FoxP}^{+}$cells, this subpopulation increased from $44.7 \% \pm 2.5$ to $51.5 \% \pm 2.1(p=0.0237)$ after Pio treatment. Collectively, this data suggests treatment with Pio favors an anti-inflammatory phenotype.

Lastly, we determined the effects of Pio on other immune populations by labeling Pio-treated and 
untreated splenocytes with anti-CD11b/c as before. Figure $4 \mathrm{c}$ shows a significant increase in the percentage of cells with a CD11b/ $\mathrm{c}^{+}$phenotype in untreated versus Pio-treated cells $(4.92 \% \pm 0.09$ versus $5.73 \% \pm 0.11$, respectively; $p=0.0007$ ).

\section{Discussion}

Two decades ago, Lehmann et al. [6], identified thiazolidinedione (TZD) derivatives as potential anti-diabetic agents in animal models of type 2 diabetes. These drugs exhibit high affinity for the peroxisome proliferator-activated receptor gamma (PPAR $\gamma$ ) ligand. PPAR $\gamma$ belongs to a family of nuclear receptors that play central roles in the regulation of metabolic homeostasis, including modulation of lipids, glucose, and bone remodeling [43-45]. This class of receptor is considered a regulator of adipose tissue inflammation and its activation increases the expression of adiponectin enhancing insulin sensitivity. Pioglitazone (Pio) is a PPAR $\gamma$ agonist used for the treatment of type 2 diabetes [46, 47]. While Pio has extensively been studied in resident cells within adipose tissue, the effects of this drug are poorly understood in secondary immune organs, such as the spleen and liver. Our work demonstrates that Pio may reverse some of the type 2 diabetes-associated pathogenesis by a de novo increase of $\mathrm{CD}^{+} \mathrm{CD} 4{ }^{+} \mathrm{CD} 31^{+} \mathrm{T}$ lymphocytes, with a concomitant reduction of pro-inflammatory mediators (TNF- $\alpha$, IL-1 $\beta$ ) and augmentation of anti-inflammatory cytokines (IL-4) in the BBDZR/Wor type 2 diabetes rat model.

Obesity, implicated in the etiology of type 2 diabetes, causes a chronic low-grade systemic inflammation contributing to metabolic dysfunction (reviewed in [48]). Clinically, type 2 diabetes is evidenced by a rise in blood glucose due to faulty insulin-dependent signaling mechanisms. Pio-dependent glucose normalization did not require weight loss in the BBZDR/Wor type 2 diabetes rat model (Fig. 1a, b), suggesting that PPAR $\gamma$ regulates additional mechanisms besides adipose tissue and body weight. The increase in adipose tissue observed in type 2 diabetes has led to focus investigations of the pro-inflammatory mediators associated with visceral adipose tissue (VAT). Two major cell populations have been investigated in the past, VAT regulatory T cells [49-53] and macrophages [23, 35, 48, 54-56]. First, Cipolleta et al., recently showed regulatory $\mathrm{T}$ cells expressing PPAR $\gamma$ suppress inflammation and regulates insulin resistance $[49,50]$. Clark and colleagues [57] demonstrated Ciglitazone, another PPAR $\gamma$ agonist, enhances regulatory $\mathrm{T}$ cells in vitro. Accordingly, our work shows upregulation of CD25 in Pio-treated splenocytes in vitro. A large portion of the $\mathrm{CD} 25^{+}$cells were positive for the FoxP3 transcription factor, considered a master regulator of natural regulatory $\mathrm{T}$ cells [40-42]. We and others, have previously shown enhancement of the FOXP3 transcription factor in human cells correlates with increases in suppressive capacity of regulatory cells $[58,59]$. Thus we speculate this population makes a major contribution to dampening of inflammation. We also speculate that the remaining FoxP3 ${ }^{\text {neg }}$ population exhibits an activated or induced regulatory $\mathrm{T}$ cell phenotype.

A number of reports have established that monocytes recruited to adipose tissue become resident macrophages [60, 61]. Macrophages accumulate in adipose tissue in both obese patients and rodents [35]. This prompted the studies to establish the linkage between an inflammatory phenotype characterized by increased levels of TNF- $\alpha$ and other pro-inflammatory cytokines and insulin resistance. Resident macrophages in adipose tissue of lean rodents showed an anti-inflammatory phenotype, or M2, whereas those of obese rodents showed a pro-inflammatory, or M1, phenotype. M1 macrophages displayed high levels of CD11c in their surface. While the mechanisms responsible for recruitment and establishment of subtypes of macrophages in VAT in diabetes are beginning to be understood, there is relatively little understanding of comparable mechanisms in other immune organs. Similar to the VAT findings, we observed a higher percentage of $\mathrm{CD} 11 \mathrm{~b} / \mathrm{c}^{+}$cells in splenocytes from diabetic rats compared to non-diabetics (Fig. 3a). This population decreased in the Pio-treated rats. Moreover, the population was not altered in the Pio-treated non-diabetic rats. These results suggests that diabetes-dependent inflammation causes an increase in the $\mathrm{CD} 11 \mathrm{~b} / \mathrm{c}^{+}$in splenocytes and that Pio-treatment reduces this population to baseline levels, as evidenced by the lack of effects in the untreated and treated non-diabetic rats.

Much of the pro-inflammatory cytokine milieu is attributed to the M1 population in VAT [39, 54, 62]. Our work revealed that non-VAT components are also contributors to the inflammation. We found $\mathrm{CD}^{+} \mathrm{T}$ lymphocytes in diabetic rats produced higher levels of TNF- $\alpha$ and IL- $1 \beta$, both pro-inflammatory mediators, compared to non-diabetic counterparts (Fig. 2a, b). Both pro-inflamatory cytokines were significantly reduced in splenocytes of Pio-treated rats, suggesting that Pio suppresses cell immune responses in non-adipose tissue. Of particular note is the reduction in IL-1 $\beta$, as this cytokine is implicated in the destruction of pancreatic $\beta$-cells [63, 64]. Reduction of pro-inflammatory cytokines may not be sufficient to control the disease. This may also be accompanied by an increase in anti-inflammatory cytokines, such as IL-4. Classically, IL-4 serves as an immunoregulatory cytokine and as a mitogen for the proliferation of cells with an anti-inflammatory phenotype [65-67]. It is important to determine the source of the IL-4 production. Our work revealed that in the spleen, $\mathrm{CD}^{+} \mathrm{T}$ 
lymphocytes, not $\mathrm{CD} 3^{\text {neg }}$ cells, were a major source of IL-4 (Fig. 2c). Together, this work suggests splenic components are contributors to the control of inflammation in Pio-treated diabetic rats.

Using our BBZDR/Wor rat model, we found Pio treatment in vivo caused an increase in recent thymic emigrants, which may contribute to the increase in percentage of total $\mathrm{T}$ lymphocytes, resulting in alleviation of lymphopenia observed in untreated BBZDR/Wor rats. Previous work in type 1 , not type 2 , diabetes rat models showed reduction of recent thymic emigrants is due, in part to defective intrathymic selection leading to autoimmunity [68]. Subsequent reports by Ramanathan and colleagues [69] confirmed these results. Rodent models of obesity based on mutations in leptin-coding gene $\left(L e p^{o b} / L e p^{o b}\right)$ have shown thymic involution that reduces $\mathrm{T}$ cell responses and the number of $\mathrm{T}$ cell emigrants to the periphery [70]. This suggests that there is a compound effect of diabetes coupled with obesity. Here, we show first, type 2 diabetic BBZDR/Wor rats have reduced frequency of recent thymic emigrants and second, a Piodependent increase in recent thymic emigrants in diabetic rats, independent of their body weight. Our work suggests the effects are Pio-dependent as we observed an increase in recent thymic emigrants in non diabetic rats with normal blood glucose levels. Still, we cannot rule out there might be compound effects by the reduction in blood glucose in addition to Pio-treatment, as shown in the diabetic + Pio group. Recent work suggests Pio and other TZDs can act in PPAR $\gamma$ dependent and independent manner (reviewed in [71]). This new data provides an additional complexity level to our study and others as it demonstrated reduction in the pro-inflammatory milieu could happen independent of PPAR $\gamma$ signaling in the presence of Pio and other TZDs. Our work shows the presence of PPAR $\gamma$ in the rats hepatocytes and splenocytes. Interestingly, our study opens new investigations to integrate multiple signaling pathways that could facilitate type 2 diabetes therapeutics. Some provocative scientific concerns are if other blood glucose lowering drugs will exhibit similar in vivo results; and how does insulin receptor signaling is affected by Pio. There is a need for more biochemical studies to understand the basis of Pio's actions.

Our investigation suggests there is promising potential for immune modulation therapy in type 2 diabetes using the TZD-derivative, Pioglitazone. More work is required to elucidate how the PPAR $\gamma$-signaling pathway, via Pio, interacts with multiple cellular pathways, including surface receptors, signals driving proliferative and suppressive responses, and transcriptional regulators. Future studies aimed at investigating how to improve immune surveillance and control the complications of type 2 diabetes could provide new strategies for improving the quality of life of diabetic patients.

\section{Authors' contributions}

BTG performed experiments, interpreted data, wrote part of the manuscript; RPL contributed to data interpretation and wrote part of the manuscript; JY performed experiments; JJS contributed to study design and provided financial support; VMT contributed to study design, performed experiments, interpret data, provided financial support and wrote the manuscript. All authors read and approved the final manuscript.

\section{Author details}

${ }^{1}$ Department of Ophthalmology, College of Medicine, The University of Tennessee Health Science Center, Memphis, TN 38163, USA. ${ }^{2}$ Department of Anatomy and Neurobiology, College of Medicine, The University of Tennessee Health Science Center, Memphis, TN 38163, USA. ${ }^{3}$ Department of Microbiology, Immunology and Biochemistry, College of Medicine, The University of Tennessee Health Science Center, Memphis, TN 38163, USA. ${ }^{4}$ Present Address: Department of Anatomy and Cell Biology, Wayne State University School of Medicine, Detroit, MI, USA.

\section{Acknowledgements}

Authors would like to thank members of Dr. Jena Steinle Lab for helpful discussions and Dr. Dianna Johnson for helpful comments.

\section{Compliance with ethical guidelines}

\section{Competing interests}

The authors declare that they have no competing interests. VMT is the guarantor of this work and, as such, had full access to all the data in the study and takes responsibility for the integrity of the data and the accuracy of the data analysis.

Received: 22 January 2015 Accepted: 19 August 2015

Published online: 02 September 2015

\section{References}

1. Association AD. Diabetes statistics: data from the 2012 National Diabetes Fact Sheet., Alexandria, Virginia. 2012. http://www.diabetes.org/diabetesbasics/diabetes-statistics/. Accessed 1 Dec 2014.

2. Adebayo O, Willis GC. The changing face of diabetes in America. Emerg Med Clin North Am. 2014;32(2):319-27. doi:10.1016/j.emc.2013.12.004

3. Organization. WH. World Health Organization: 10 facts about diabetes. 2011.

4. Donath MY, Shoelson SE. Type 2 diabetes as an inflammatory disease. Nat Rev Immunol. 2011;11(2):98-107. doi:10.1038/nri2925.

5. Yau H, Rivera K, Lomonaco R, Cusi K. The future of thiazolidinedione therapy in the management of type 2 diabetes mellitus. Curr Diab Rep. 2013;13(3):329-41. doi:10.1007/s11892-013-0378-8.

6. Lehmann JM, Moore LB, Smith-Oliver TA, Wilkison WO, Willson TM, Kliewer SA. An antidiabetic thiazolidinedione is a high affinity ligand for peroxisome proliferator-activated receptor gamma (PPAR gamma). J Biol Chem. 1995;270(22):12953-6.

7. Sinha B, Ghosal S. Pioglitazone-do we really need it to manage type 2 diabetes? Diabetes Metab Syndr. 2013;7(4):243-6. doi:10.1016/j. dsx.2013.06.005.

8. Wang L, Waltenberger B, Pferschy-Wenzig EM, Blunder M, Liu X, Malainer $C$, et al. Natural product agonists of peroxisome proliferator-activated receptor gamma (PPARgamma): a review. Biochem Pharmacol. 2014;. doi:10.1016/j.bcp.2014.07.018.

9. Hofmann C, Lorenz K, Braithwaite SS, Colca JR, Palazuk BJ, Hotamisligil GS, et al. Altered gene expression for tumor necrosis factor-alpha and its receptors during drug and dietary modulation of insulin resistance. Endocrinology. 1994;134(1):264-70. doi:10.1210/endo.134.1.8275942.

10. Ikeda H, Taketomi S, Sugiyama Y, Shimura Y, Sohda T, Meguro K, et al. Effects of pioglitazone on glucose and lipid metabolism in normal and insulin resistant animals. Arzneimittelforschung. 1990;40(2 Pt 1):156-62. 
11. Sugiyama $Y$, Shimura $Y$, Ikeda $H$. Effects of pioglitazone on hepatic and peripheral insulin resistance in Wistar fatty rats. Arzneimittelforschung. 1990;40(4):436-40.

12. Sugiyama $Y$, Taketomi S, Shimura Y, Ikeda H, Fujita T. Effects of pioglitazone on glucose and lipid metabolism in Wistar fatty rats. Arzneimittelforschung. 1990;40(3):263-7

13. Kemnitz JW, Elson DF, Roecker EB, Baum ST, Bergman RN, Meglasson MD. Pioglitazone increases insulin sensitivity, reduces blood glucose, insulin, and lipid levels, and lowers blood pressure, in obese, insulin-resistant rhesus monkeys. Diabetes. 1994;43(2):204-11.

14. Hallakou S, Doare L, Foufelle F, Kergoat M, Guerre-Millo M, Berthault MF, et al. Pioglitazone induces in vivo adipocyte differentiation in the obese Zucker fa/fa rat. Diabetes. 1997;46(9):1393-9.

15. Suzuki A, Yasuno T, Kojo H, Hirosumi J, Mutoh S, Notsu Y. Alteration in expression profiles of a series of diabetes-related genes in $\mathrm{db} / \mathrm{db}$ mice following treatment with thiazolidinediones. Jpn J Pharmacol. 2000;84(2):113-23.

16. Fujimoto M, Tsuneyama K, Fujimoto T, Selmi C, Gershwin ME, Shimada Y. Spirulina improves non-alcoholic steatohepatitis, visceral fat macrophage aggregation, and serum leptin in a mouse model of metabolic syndrome. Dig Liver Dis. 2012;44(9):767-74. doi:10.1016/j.dld.2012.02.002.

17. Spencer M, Yang L, Adu A, Finlin BS, Zhu B, Shipp LR, et al. Pioglitazone treatment reduces adipose tissue inflammation through reduction of mast cell and macrophage number and by improving vascularity. PLoS One. 2014;9(7):e102190. doi:10.1371/journal.pone.0102190.

18. Uchiyama M, Shimizu A, Masuda Y, Nagasaka S, Fukuda Y, Takahashi H. An ophthalmic solution of a peroxisome proliferator-activated receptor gamma agonist prevents corneal inflammation in a rat alkali burn model. Mol Vision. 2013;19:2135-50

19. Jiang Y, Thakran S, Bheemreddy R, Ye EA, He H, Walker RJ, et al. Pioglitazone normalizes insulin signaling in the diabetic rat retina through reduction in tumor necrosis factor alpha and suppressor of cytokine signaling 3. J Biol Chem. 2014:289(38):26395-405. doi:10.1074/jbc.M114.583880.

20. Uchimura K, Nakamuta M, Enjoji M, Irie T, Sugimoto R, Muta T, et al. Activation of retinoic $X$ receptor and peroxisome proliferator-activated receptor-gamma inhibits nitric oxide and tumor necrosis factor-alpha production in rat Kupffer cells. Hepatology. 2001;33(1):91-9. doi:10.1053/ jhep.2001.21145.

21. Majai G, Sarang Z, Csomos K, Zahuczky G, Fesus L. PPARgamma-dependent regulation of human macrophages in phagocytosis of apoptotic cells. Eur J Immunol. 2007;37(5):1343-54. doi:10.1002/eji.200636398.

22. Hasegawa H, Takano H, Zou Y, Qin Y, Hizukuri K, Odaka K, et al. Pioglitazone, a peroxisome proliferator-activated receptor gamma activator ameliorates experimental autoimmune myocarditis by modulating Th1/Th2 balance. J Mol Cell Cardiol. 2005;38(2):257-65. doi:10.1016/j. yjmcc.2004.11.010.

23. Thorp E, Kuriakose G, Shah YM, Gonzalez FJ, Tabas I. Pioglitazone increases macrophage apoptosis and plaque necrosis in advanced atherosclerotic lesions of nondiabetic low-density lipoprotein receptor-null mice. Circulation. 2007;116(19):2182-90. doi:10.1161/CIRCULATIONAHA.107.698852.

24. Zhao W, Berthier CC, Lewis EE, McCune WJ, Kretzler M, Kaplan MJ. The peroxisome-proliferator activated receptor-gamma agonist pioglitazone modulates aberrant T cell responses in systemic lupus erythematosus. Clin Immunol. 2013;149(1):119-32. doi:10.1016/j.clim.2013.07.002.

25. Jiang Y, Zhang Q, Steinle JJ. Intravitreal injection of IGFBP-3 restores normal insulin signaling in diabetic rat retina. PLoS One. 2014;9(4):e93788. doi:10.1371/journal.pone.0093788.

26. Walker RJ, Steinle JJ. Role of beta-adrenergic receptors in inflammatory marker expression in Muller cells. Invest Ophthalmol Vis Sci. 2007:48(11):5276-81. doi:10.1167/iovs.07-0129.

27. Kohler S, Thiel A. Life after the thymus: CD31+ and CD31- human naive CD4+ T-cell subsets. Blood. 2009;113(4):769-74. doi:10.1182/ blood-2008-02-139154.

28. Lontchi-Yimagou E, Sobngwi E, Matsha TE, Kengne AP. Diabetes mellitus and inflammation. Curr Diab Rep. 2013;13(3):435-44. doi:10.1007/ s11892-013-0375-y.

29. Imai Y, Dobrian AD, Weaver JR, Butcher MJ, Cole BK, Galkina EV, et al. Interaction between cytokines and inflammatory cells in islet dysfunction, insulin resistance and vascular disease. Diabetes Obes Metab. 2013;15(Suppl 3):117-29. doi:10.1111/dom.12161.
30. De Carvalho Vidigal F, Guedes Cocate P, Goncalves Pereira L, De Cassia Goncalves Alfenas R. The role of hyperglycemia in the induction of oxidative stress and inflammatory process. Nutr Hosp. 2012;27(5):1391-8. doi:10.3305/nh.2012.27.5.5917.

31. Donath MY, Schumann DM, Faulenbach M, Ellingsgaard H, Perren A, Ehses JA. Islet inflammation in type 2 diabetes: from metabolic stress to therapy. Diabetes Care. 2008;31(Suppl 2):S161-4. doi:10.2337/dc08-s243.

32. Pereira FO, Frode TS, Medeiros YS. Evaluation of tumour necrosis factor alpha, interleukin-2 soluble receptor, nitric oxide metabolites, and lipids as inflammatory markers in type 2 diabetes mellitus. Mediators Inflamm. 2006;2006(1):39062. doi:10.1155/MI/2006/39062.

33. Bano G. Glucose homeostasis, obesity and diabetes. Best Pract Res Clin Obstet Gynaecol. 2013;27(5):715-26. doi:10.1016/j.bpobgyn.2013.02.007.

34. Shoelson SE, Lee J, Goldfine AB. Inflammation and insulin resistance. J Clin Invest. 2006;116(7):1793-801. doi:10.1172/JCI29069.

35. Weisberg SP, McCann D, Desai M, Rosenbaum M, Leibel RL, Ferrante AW $\mathrm{Jr}$. Obesity is associated with macrophage accumulation in adipose tissue. J Clin Invest. 2003;112(12):1796-808. doi:10.1172/JCl19246.

36. Xu H, Barnes GT, Yang Q, Tan G, Yang D, Chou CJ, et al. Chronic inflammation in fat plays a crucial role in the development of obesity-related insulin resistance. J Clin Invest. 2003;112(12):1821-30. doi:10.1172/JCI19451.

37. Bouhlel MA, Derudas B, Rigamonti E, Dievart R, Brozek J, Haulon S, et al. PPARgamma activation primes human monocytes into alternative M2 macrophages with anti-inflammatory properties. Cell Metab. 2007;6(2):137-43. doi:10.1016/j.cmet.2007.06.010.

38. Ricote M, Li AC, Willson TM, Kelly CJ, Glass CK. The peroxisome proliferator-activated receptor-gamma is a negative regulator of macrophage activation. Nature. 1998;391(6662):79-82. doi:10.1038/34178.

39. Fujisaka S, Usui I, Bukhari A, Ikutani M, Oya T, Kanatani Y, et al. Regulatory mechanisms for adipose tissue M1 and M2 macrophages in diet-induced obese mice. Diabetes. 2009:58(11):2574-82. doi:10.2337/db08-1475.

40. Fontenot JD, Gavin MA, Rudensky AY. Foxp3 programs the development and function of CD4 + CD25 + regulatory T cells. Nat Immunol. 2003;4(4):330-6. doi:10.1038/ni904.

41. Hori S, Nomura T, Sakaguchi S. Control of regulatory T cell development by the transcription factor Foxp3. Science. 2003;299(5609):1057-61. doi:10.1126/science.1079490.

42. Khattri R, CoxT, Yasayko SA, Ramsdell F. An essential role for Scurfin in CD4+ CD25+ T regulatory cells. Nat Immunol. 2003;4(4):337-42. doi:10.1038/ni909.

43. Subramani PA, Reddy MC, Narala VR. The need for physiologically relevant peroxisome proliferator-activated receptor-gamma (PPAR-gamma) ligands. Endocr Metab Immune Disord Drug Targets. 2013;13(2):175-83.

44. Ahmadian M, Suh JM, Hah N, Liddle C, Atkins AR, Downes M, et al. PPARgamma signaling and metabolism: the good, the bad and the future. Nat Med. 2013;19(5):557-66. doi:10.1038/nm.3159.

45. Ferroni P, Della-Morte D, Pileggi A, Riondino S, RundekT, Ricordi C, et al. Pleiotropic effects of PPARgamma agonist on hemostatic activation in type 2 diabetes mellitus. Curr Vasc Pharmacol. 2013;11(3):338-51.

46. Hofmann CA, Colca JR. New oral thiazolidinedione antidiabetic agents act as insulin sensitizers. Diabetes Care. 1992;15(8):1075-8.

47. Hofmann CA, Edwards CW 3rd, Hillman RM, Colca JR. Treatment of insulin-resistant mice with the oral antidiabetic agent pioglitazone: evaluation of liver GLUT2 and phosphoenolpyruvate carboxykinase expression. Endocrinology. 1992;130(2):735-40. doi:10.1210/endo.130.2.1733721.

48. McNelis JC, Olefsky JM. Macrophages, immunity, and metabolic disease. Immunity. 2014;41(1):36-48. doi:10.1016/j.immuni.2014.05.010.

49. Cipolletta D. Adipose tissue-resident regulatory T cells: phenotypic specialization, functions and therapeutic potential. Immunology. 2014;142(4):517-25. doi:10.1111/imm.12262.

50. Cipolletta D, Feuerer M, Li A, Kamei N, Lee J, Shoelson SE, et al. PPARgamma is a major driver of the accumulation and phenotype of adipose tissue Treg cells. Nature. 2012;486(7404):549-53. doi:10.1038/ nature 11132

51. Cipolletta D, Cohen P, Spiegelman BM, Benoist C, Mathis D. Appearance and disappearance of the mRNA signature characteristic of Treg cells in visceral adipose tissue: age, diet, and PPARgamma effects. Proc Natl Acad Sci USA. 2015;112(2):482-7. doi:10.1073/pnas.1423486112.

52. Cipolletta D, Kolodin D, Benoist C, Mathis D. Tissular T(regs): a unique population of adipose-tissue-resident Foxp3+ CD4+ T cells that impacts 
organismal metabolism. Semin Immunol. 2011;23(6):431-7. doi:10.1016/j. smim.2011.06.002.

53. Deiuliis J, Shah Z, Shah N, Needleman B, Mikami D, Narula V, et al. Visceral adipose inflammation in obesity is associated with critical alterations in tregulatory cell numbers. PLoS One. 2011;6(1):e16376. doi:10.1371/journal.pone.0016376.

54. Kraakman MJ, Murphy AJ, Jandeleit-Dahm K, Kammoun HL. Macrophage polarization in obesity and type 2 diabetes: weighing down our understanding of macrophage function? Front Immunol. 2014;5:470. doi:10.3389/fimmu.2014.00470.

55. Kanda H, Tateya S, Tamori Y, Kotani K, Hiasa K, Kitazawa R, et al. MCP-1 contributes to macrophage infiltration into adipose tissue, insulin resistance, and hepatic steatosis in obesity. J Clin Invest. 2006;1 16(6):1494-505. doi:10.1172/JC126498.

56. Nagy ZS, Czimmerer Z, Szanto A, Nagy L. Pro-inflammatory cytokines negatively regulate PPARgamma mediated gene expression in both human and murine macrophages via multiple mechanisms. Immunobiology. 2013;218(11):1336-44. doi:10.1016/j.imbio.2013.06.011.

57. Wohlfert EA, Nichols FC, Nevius E, Clark RB. Peroxisome proliferatoractivated receptor gamma (PPARgamma) and immunoregulation: enhancement of regulatory T cells through PPARgamma-dependent and -independent mechanisms. J Immunol. 2007;178(7):4129-35.

58. Morales-Tirado V, Wichlan DG, Leimig TE, Street SE, Kasow KA, Riberdy JM. 1alpha,25-dihydroxyvitamin D3 (vitamin D3) catalyzes suppressive activity on human natural regulatory $T$ cells, uniquely modulates cell cycle progression, and augments FOXP3. Clin Immunol. 2011;138(2):212-21. doi:10.1016/j.clim.2010.11.003.

59. Kasow KA, Morales-Tirado VM, Wichlan D, Shurtleff SA, Abraham A, Persons DA, et al. Therapeutic in vivo selection of thymic-derived natural T regulatory cells following non-myeloablative hematopoietic stem cell transplant for IPEX. Clin Immunol. 2011;141(2):169-76. doi:10.1016/j. clim.2011.07.005.

60. Curat CA, Miranville A, Sengenes C, Diehl M, Tonus C, Busse R, et al. From blood monocytes to adipose tissue-resident macrophages: induction of diapedesis by human mature adipocytes. Diabetes. 2004;53(5):1285-92

61. Kamei N, Tobe K, Suzuki R, Ohsugi M, Watanabe T, Kubota N, et al. Overexpression of monocyte chemoattractant protein-1 in adipose tissues causes macrophage recruitment and insulin resistance. J Biol Chem. 2006;281 (36):26602-14. doi:10.1074/jbc.M601284200.

62. Haase J, Weyer U, Immig K, Kloting N, Bluher M, Eilers J, et al. Local proliferation of macrophages in adipose tissue during obesity-induced inflammation. Diabetologia. 2014;57(3):562-71. doi:10.1007/s00125-013-3139-y.

63. Maedler K, Sergeev P, Ris F, Oberholzer J, Joller-Jemelka HI, Spinas GA, et al. Glucose-induced beta cell production of IL-1 beta contributes to glucotoxicity in human pancreatic islets. J Clin Invest. 2002;110(6):851-60. doi:10.1172/JCl15318.

64. Wachlin G, Augstein P, Schroder D, Kuttler B, Kloting I, Heinke P, et al. IL-1 beta, IFN-gamma and TNF-alpha increase vulnerability of pancreatic beta cells to autoimmune destruction. J Autoimmun. 2003;20(4):303-12.

65. Severinson E, Naito T, Tokumoto H, Fukushima D, Hirano A, Hama K, et al. Interleukin 4 (IgG1 induction factor): a multifunctional lymphokine acting also on T cells. Eur J Immunol. 1987;17(1):67-72. doi:10.1002/ eji.1830170112.

66. Fowell DJ, Magram J, Turck CW, Killeen N, Locksley RM. Impaired Th2 subset development in the absence of CD4. Immunity. 1997;6(5):559-69.

67. Mosmann TR, Coffman RL. Two types of mouse helper T-cell clone Implications for immune regulation. Immunol Today. 1987;8(7-8):223-7. doi:10.1016/0167-5699(87)90171-X.

68. Zadeh HH, Greiner DL, Wu DY, Tausche F, Goldschneider I. Abnormalities in the export and fate of recent thymic emigrants in diabetes-prone BB/W rats. Autoimmunity. 1996;24(1):35-46.

69. Poussier P, Ning T, Murphy T, Dabrowski D, Ramanathan S. Impaired post-thymic development of regulatory $C D 4+25+T$ cells contributes to diabetes pathogenesis in BB rats. J Immunol. 2005;174(7):4081-9.

70. Hick RW, Gruver AL, Ventevogel MS, Haynes BF, Sempowski GD. Leptin selectively augments thymopoiesis in leptin deficiency and lipopolysaccharide-induced thymic atrophy. J Immunol. 2006;177(1):169-76.

71. Feinstein DL, Spagnolo A, Akar C, Weinberg G, Murphy P, Gavrilyuk V, et al. Receptor-independent actions of PPAR thiazolidinedione agonists: is mitochondrial function the key? Biochem Pharmacol. 2005;70(2):177-88, doi:10.1016/j.bcp.2005.03.033.

\section{Submit your next manuscript to BioMed Central and take full advantage of:}

- Convenient online submission

- Thorough peer review

- No space constraints or color figure charges

- Immediate publication on acceptance

- Inclusion in PubMed, CAS, Scopus and Google Scholar

- Research which is freely available for redistribution

Submit your manuscript at

www.biomedcentral.com/submit
( Biomed Central 